Department of Pharmacology (Prof. H. Yamasaki), Okayama University Medical School, Okayama and Department of Anatomy (Prof. T. Fujita), Niigata University School of Medicine,

Niigata, Japan

\title{
Electron Microscope Studies on the Release of Histamine from Rat Peritoneal Mast Cells*
}

\author{
Hidemasa Yamasaki, Tsuneo Fujita, Yasuro Ohara and Shigemitsu Kомото \\ （山崎英正，藤田恒夫，尾原安郎，古元重光）
}

Received September 10, 1969

The occurrence of histamine in the granules of mammalian mast cells has been established by combined bioassay and histological studies (RILEY and WEST, 1953), by chemical analysis of the granule fraction (HAGEN, BARRNETT and LEE, 1959) and further by fluorescence histochemistry for histamine (JuHLin and SHELley, 1966; YAMASAKI, 1967; TaKaya, 1969). Certain substances such as compound 48/80 (Paton, 1951; FawCETt, 1954), Sinomenine (MAYeda, 1953; Yamasaki et al., 1955), toluidine blue (CAmble, 1952; Smith, 1958a) and anti-serum (Keller and Schwarz, 1961; Saeki, 1964) have been known to cause the release of histamine from mast cells with accompanying morphological changes in these cells such as degranulation and vacuolation. A large number of works have been directed to the morphological studies with special interest in the nature of cytological alterations in mast cells since these changes seemed to be an essential feature of the processes causally involved in the mechanisms of histamine release.

As for the electron microscopic studies on the mast cell reactions to histamine liberators, there have been observations using compound $48 / 80$ and other basic materials (Smith and Lewis, 1957; Bloom, Larsson and SMith, 1957; Horsfield, 1965; Bloom and Haegermark, 1965; Singleton and Clark, 1965). However, these studies seem to have not yet fully established the morphological criteria of the release of histamine. Some authors have regarded degranulation as the essential morphological manifestation of histamine liberation (FAWCETT, 1954; RILEY and WEST, 1955; UvNës, 1964), while others thought much of either vacuolation (BLoom, LARsson and SMith, 1957; SMITH and Lewis, 1957) or alteration in the granule structure (BLOOM and HAEGERMARK, 1965). Further, as to how the histamine-liberating agents act on the cell parts, be it the cell membrane, cytoplasm, or granule itself, remains quite unknown.

In the present investigation the effects of compound $48 / 80$, sinomenine, toluidine blue and rabbit anti-rat serum on the mast cells in the rat peritoneal fluid were examined under the electron microscope. Special reference was made to the correlation between the morphological changes and the degree of histamine release from mast cells in order to find out whether extracellular discharge of granules is really essential for the histamine release induced by these histamine-liberating agents. The effect of the inhibitor of histamine release, 2,4-dinitrophenol, was also examined morphologically.

\footnotetext{
* The main part of this study was published in Japanese (OHARA, 1969). This paper is dedicated to Professor Toshio Iто on the occasion of his retirement.
} 


\section{Materials and Methods}

\section{Collection of peritoneal mast cells}

Male albino rats $(200-300 \mathrm{~g})$ of the Wistar strain were bled by severing the carotid arteries under ether anesthesia and $10 \mathrm{ml}$ of buffered physiological solution $(\mathrm{NaCl}, 154$ $\mathrm{mM}$; $\mathrm{KCl}, 2.7 \mathrm{mM} ; \mathrm{CaCl}_{2}, 0.9 \mathrm{mM} ; 1 / 10$ volume of $0.1 \mathrm{M}$ phosphate buffer, $\mathrm{pH} 7.2$ ) were injected into the peritoneal cavity. After gentle massage for 2 min of the gut through the abdominal wall, the wall was incised along the midvental line and the fluid from the peritoneal cavity was sucked off and pipetted into $15 \mathrm{ml}$ conical glass tubes, then centrifuged $(100 \times \mathrm{g}, 3 \mathrm{~min})$ at $1-4^{\circ} \mathrm{C}$. The supernatant was gently decanted. The sediment thus obtained generally gave a mast cell count of 5-6\% against the total cell number. For the study of the normal mast cell the sediment was fixed immediately as described below.

\section{Treatment with histamine liberators}

Use was made of compound 48/80 (provided by Burrough Wellcome \& Co., Tuchahoe, N. Y.), sinomenine hydrochloride (Shionogi Pharmaceutical Co.), toluidine blue-O (Merck) and rabbit anti-rat serum (SAEKI, 1964). These substances were dissolved in the above mentioned physiological solution to make required concentrations as follows: compound 48/80, 0.1, 1.0, 5.0 and $100 \mu \mathrm{g} / \mathrm{ml}$; sinomenine, $500 \mu \mathrm{g} / \mathrm{ml}$; toluidine blue, $50 \mu \mathrm{g} / \mathrm{ml}$; anti-serum, $10 \% \mathrm{v} / \mathrm{v}$, respectively. Sediments of the peritoneal washing in the centrifugation tubes were added to $2 \mathrm{ml}$ of these solutions and mixed, then incubated at $37^{\circ} \mathrm{C}$ for $15 \mathrm{~min}$ and cooled in an ice bath to stop the reaction immediately after termination of the incubation. The mixtures were centrifuged for $3 \mathrm{~min}(100 \times \mathrm{g})$ and the resulting sediments were fixed for electron microscopic examination.

\section{Treatment with histamine-release inhibitor}

The sediment of the peritoneal washing was mixed with $2 \mathrm{ml}$ of the physiological solution containing 2, 4-dinitrophenol (DNP), $10^{-4} \mathrm{M}$. This concentration was known to be sufficient to inhibit degranulation and histamine release by compound $48 / 80$ from mast cells, when the medium is free of glucose (Diamant and Uvnäs, 1961; SaEki, 1964). After $15 \mathrm{~min}$ incubation at $37^{\circ} \mathrm{C}, 2 \mathrm{ml}$ of $2.0 \mu \mathrm{g} / \mathrm{ml}$ of compound $48 / 80$ was added (final concentration: $1.0 \mu \mathrm{g} / \mathrm{ml}$ ) and incubated for another $15 \mathrm{~min}$, then cooled in an ice bath. Tubes were centrifuged, and sediments were submitted for fixation. Sediments similarly obtained but omitting the incubation with compound $48 / 80$ served as controls.

\section{Histamine determination}

The histamine in the supernatants and the corresponding sediments was determined on the atropinized guinea-pig ileum. The sediment fractions were resuspended in the physiological solution. Both fractions were heated in a boiling bath for $3 \mathrm{~min}$, and assessed for histamine content.

\section{Preparation for electron microscopy}

One $\mathrm{ml}$ of $3 \%$ glutaraldehyde (in $0.1 \mathrm{M}$ phosphate buffer, $\mathrm{pH} 7.2$ ) was gently layered on the sediment obtained by centrifugation and left for $10 \mathrm{~min}$ at $4^{\circ} \mathrm{C}$. The sediment then was removed by a needle from the centrifugation tube and cut into 
$0.5 \mathrm{~mm}$ cubes with a razor blade to be refixed in $3 \%$ glutaraldehyde for $4 \mathrm{hrs}\left(4^{\circ} \mathrm{C}\right)$. The cubes were then washed in phosphate buffer ( $\mathrm{pH} \mathrm{7.2)} \mathrm{for} 12 \mathrm{hrs}$, post-fixed in a $1 \%$ solution of $\mathrm{OsO}_{4}$ in phosphate buffer for $4 \mathrm{hrs}\left(4^{\circ} \mathrm{C}\right)$ and dehydrated in a series of ascending concentrations of ethanol and propylene oxide to be embedded in Epon 812 . Sections cut with glass knives on a Porter-Blum microtome and stained in lead monoxide (KARNovsky, 1961) or in lead acetate (MuLLoniG, 1961) were observed with a HU11 and a JEM-7 type electron microscope.

\section{Results}

\section{A. Histamine Release}

Table 1 shows the histamine release by compound $48 / 80$ and three other histaminereleasing agents from peritoneal cell suspensions under conditions corresponding to those in making electron microscopic preparations. In this table the inhibitory effect, which is virtually complete, of DNP $\left(10^{-4} \mathrm{M}\right)$ on the histamine-releasing action of $48 / 80$ $(1 \mu \mathrm{g} / \mathrm{ml})$ is also indicated. All values of percent histamine release include spontaneous release which ranges from 1.5 to $4.1 \%$.

Table 1. Histamine release from rat peritoneal cells. Histamine release computed in per cent of total histamine content. Means with standard errors of mean from 5-7 experiments.

\begin{tabular}{lcc}
\hline \multicolumn{1}{c}{ Treatment } & & Histamine release \\
\hline None & & $2.8 \pm 0.5$ \\
Compound $48 / 80$ & $0.1 \mu \mathrm{g} / \mathrm{ml}$ & $37.9 \pm 5.9$ \\
& 0.5 & $72.0 \pm 1.7$ \\
& 1.0 & $81.0 \pm 1.8$ \\
& 5.0 & $89.5 \pm 2.1$ \\
& 10 & $89.9 \pm 1.7$ \\
Toluidine blue & 100 & $90.7 \pm 3.9$ \\
Sinomenine & 50 & $76.0 \pm 2.3$ \\
Anti-rat serum & 500 & $72.4 \pm 5.1$ \\
DNP & $10 \%(\mathrm{v} / \mathrm{v})$ & $86.2 \pm 1.3$ \\
DNP $10^{-4} \mathrm{M}+48 / 801 \mu \mathrm{g} / \mathrm{ml}$ & $10^{-4} \mathrm{M}$ & $3.0 \pm 0.3$ \\
& & $6.5 \pm 0.5$ \\
\hline
\end{tabular}

\section{B. Normal Mast Cells}

The fine structure of rat peritoneal mast cells, which were mingled with numerous eosinophils, some neutrophils, lymphocytes and a few cells of probable mesothelial and fibroblastic origins, essentially corresponded to the previous descriptions of the subcutaneous (Fujita, 1965) and intraperitoneal mast cells (Singleton and Clark, 1965; Bloom and Haegermark, 1965; Combs, 1966; Ginsburg and Lagunoff, 1967) of this species. The mast cell granules $(0.6-1.6 \mu$, mostly around $1.0 \mu)$ showed round, oval, elliptic or occasional irregular profiles (Fig. 1). They were closely enclosed by a membrane sac, though a space of $10-15 \mathrm{~m} \mu$ between the granule substance and the sac occasionally occurred. The granules generally showed, in lead-stained specimens, an electron dense and fine granular texture. It seems worth-while to note, however, that a few mast cells showed a considerable population of granules of coarser, reticular or 


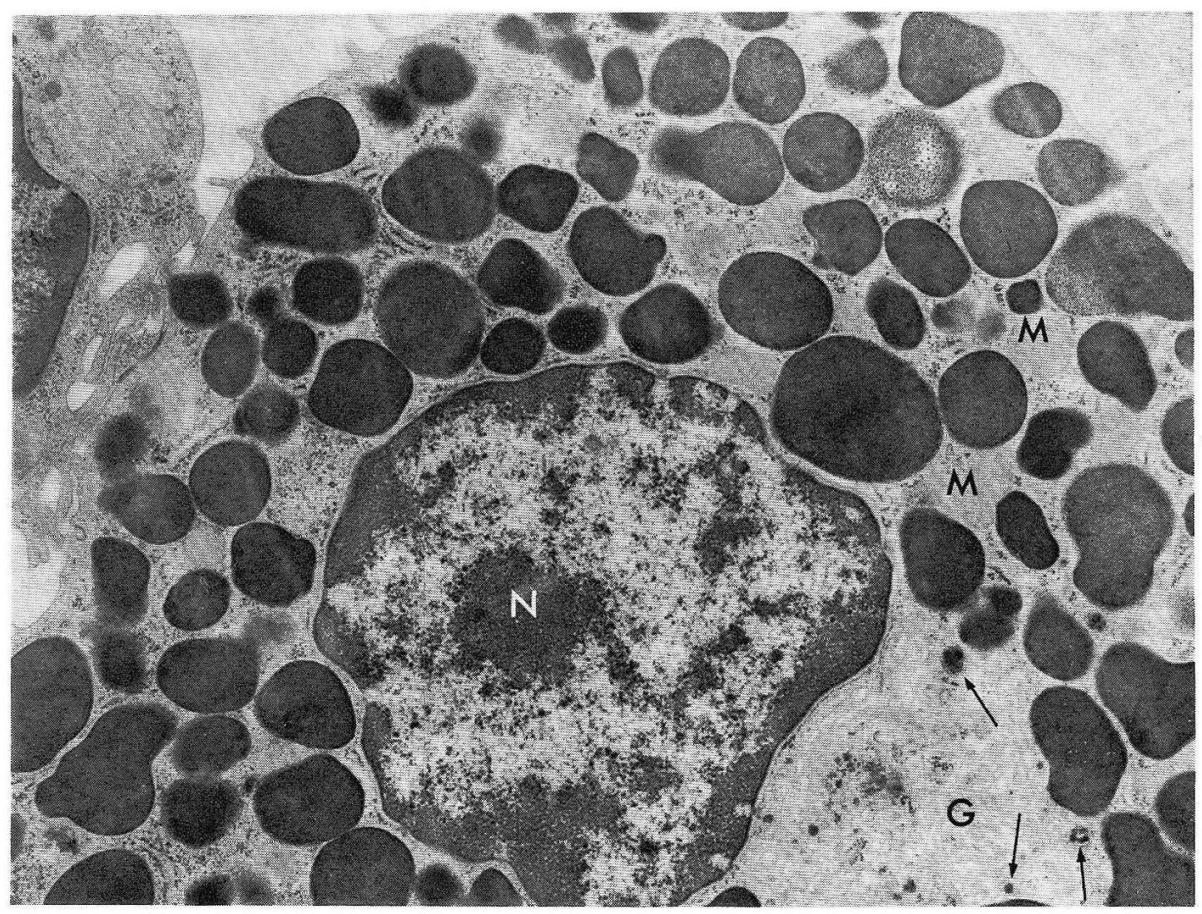

Fig. 1.

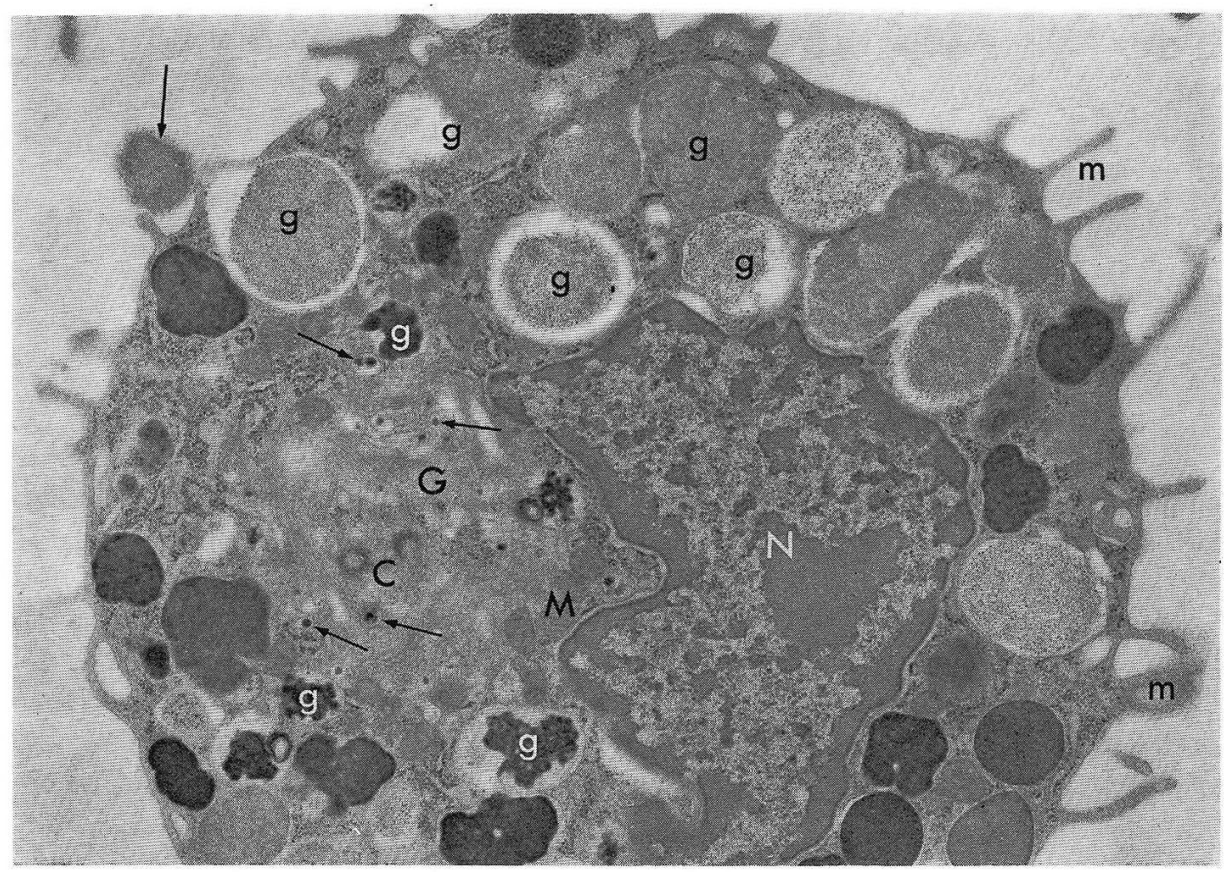

Fig. 2. 
reticulogranular appearance and of lower electron density (Fig. 2). Perigranular vacuolation and even a released granule could rarely be found in such cells.

As first pointed out by Fujita (1965) the smallest visible mast cell granules occurred in the sacs of the Golgi complex (Fig. 1,2). They seemed to grow and/or be gathered into a mulberry-like structure (Fig. 2) which developed, within its smoothsurfaced sac, into a mature granule of more homogeneous and condensed appearance. A direct connection of a cistern of rough endoplasmic reticulum to the growing granule sac described by Combs (1966) was not confirmed. No figure indicating the release of the granules from the cell was encountered in the normal mast cells.

The cytoplasm further contained a moderate number of mitochondria, elements of rough-surfaced endoplasmic reticulum and free ribosomes among the mast cell granules. In the center of the well developed Golgi complex which occupied the paranuclear region there were found a pair of centrioles (Fig. 2). The cell surface was irregularly covered by microvilli.

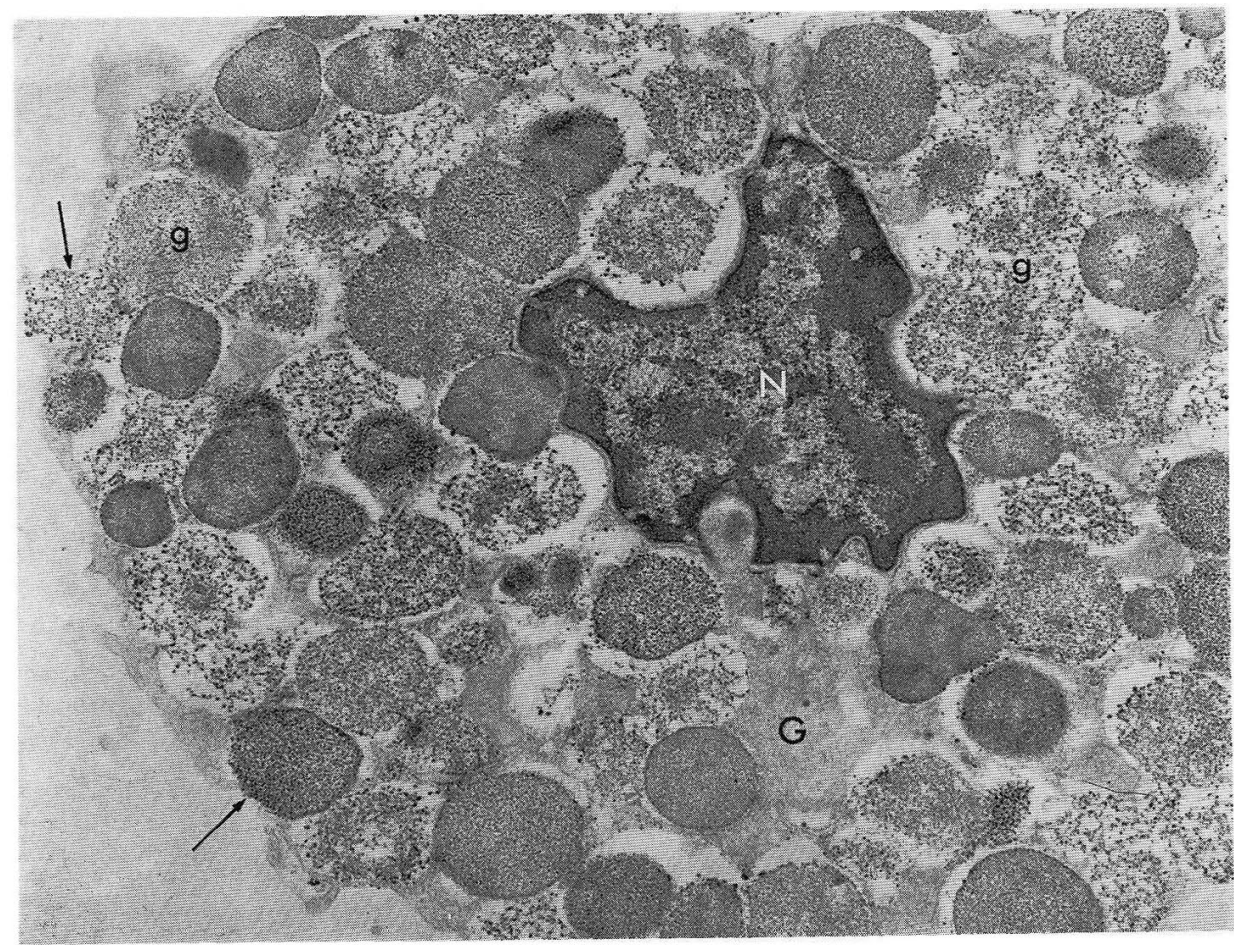

Fig. 3. A cell with strongly swollen and vacuolated granules $(g)$ after treatment with $0.1 \mu \mathrm{g} / \mathrm{ml}$ compound $48 / 80$. Some granules directly face the pericellular space. $G$ cytoplasma corresponding to the Golgi area. $\times 10,000$

Fig. 1. Normal mast cell of the rat. $N$ nucleus, $G$ Golgi area containing small granules of immature type (arrows), $M$ mitochondria. $\times 10,000$

Fig. 2. A type of cell found in the untreated material. Some granules ( $g$ in black) are loose in texture and low in electron density. In the upper left a granule is seen out of the cell (arrow). Small granules (arrows) and mulberry-like granules ( $g$ in white) are seen in and around the Golgi area $(G)$ which contains centrioles $(C)$ in its center. $m$ Microvilli. $\times 10,000$ 


\section{Effects of Histamine Liberators}

\section{Compound $48 / 80$}

$0.1 \mu \mathrm{g} / \mathrm{ml}$. Although in some mast cells no variations from the normal state were discernible under the electron microscope, others showed certain changes in the granules and their surroundings. The granules were enlarged $(0.6-2.0 \mu$, mostly around $1.2 \mu)$ and swollen in appearance. The granule texture was very loose and some granules showed only a wide-meshed and partly interrupted net of dense material. Many granules had lost their round contour and some were fused into a larger mass (Fig. 3). These alterations in the granules, though recognized only in a part of the cells, essentially corresponded to the description of Bloom and HaEgermark (1965) in the effect of the same dose of compound 48/80.

The space between the granule substance and the membrane sac was more or less widened. Some peripheral granules were found facing the pericellular space directly (Fig. 3) but virtually no degranulation was recognized with this dose of compound $48 / 80$.

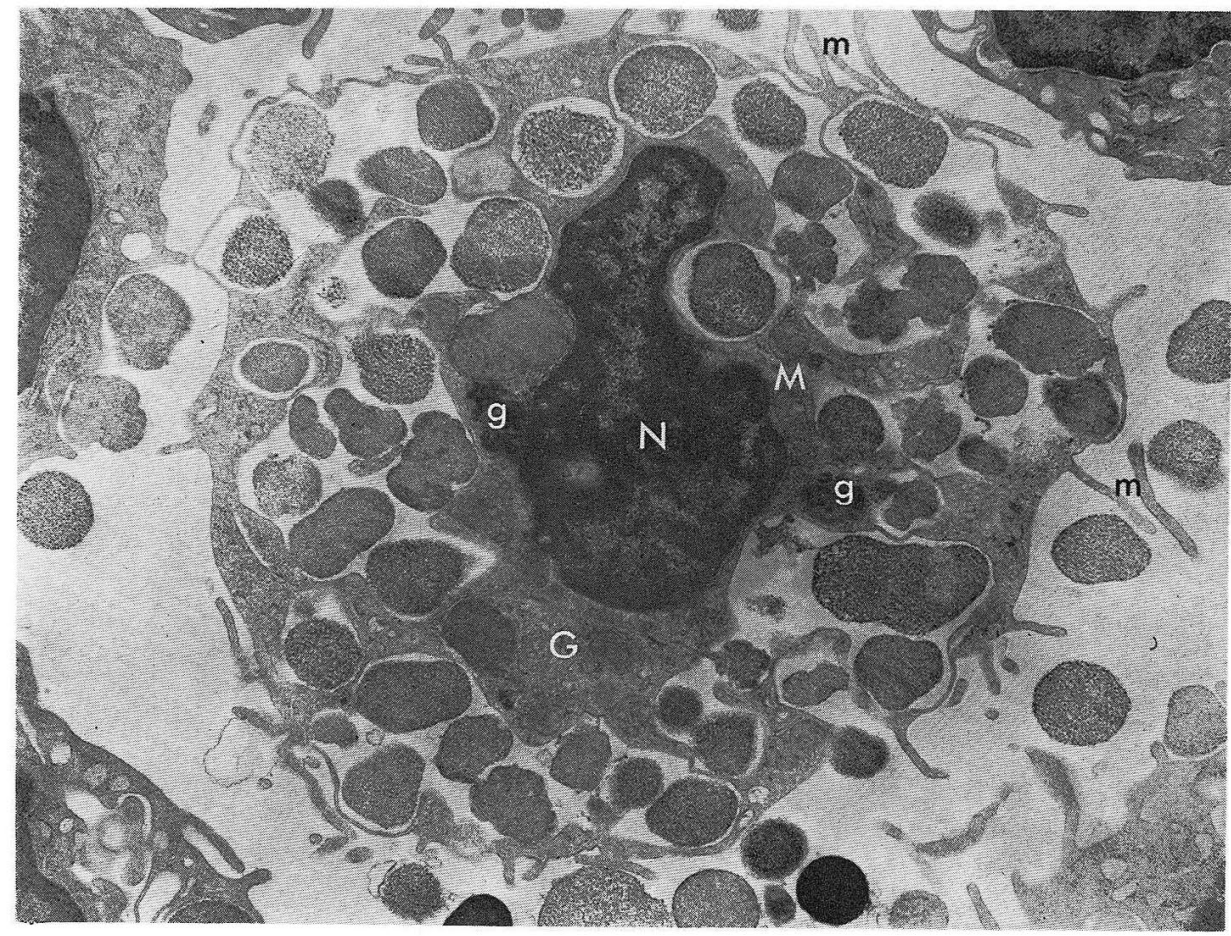

Fig. 4. "Honeycomb" cell caused by $5.0 \mu \mathrm{g} / \mathrm{ml}$ compound $48 / 80$. Note the granules in the pericellular space. The remaining cytoplasm contains Golgi area $(G)$, mitochondria and some mulberry type granules $(g) . \quad m$ Microvilli. $\times 10,000$

$0.5 \mu \mathrm{g} / \mathrm{ml}$. Most of the mast cells showed cytological changes with this dose which were characterized by more advanced changes indicating swelling and dissolving of the granules than in the preceding one, and more conspicuous perigranular vacuolation and occasional degranulation. 
The perigranular vacuoles were enlarged either individually or in such a way that some of them became fused into a large vacuole. Large vacuoles of the latter type, often filling nearly half of the cytoplasmic area in the section, favored the peripheral portion of the cell leaving a thin cytoplasmic sheet $(50-150 \mathrm{~m} \mu$ thick) beneath the cell membrane. This sheet was occasionally interrupted and there the fluid in the vacuoles seemed to communicate to the pericellular space.

It deserves to be noticed that the granules varied in the degree of their morphological changes even within a single cell; adjacent to granules whose visible material

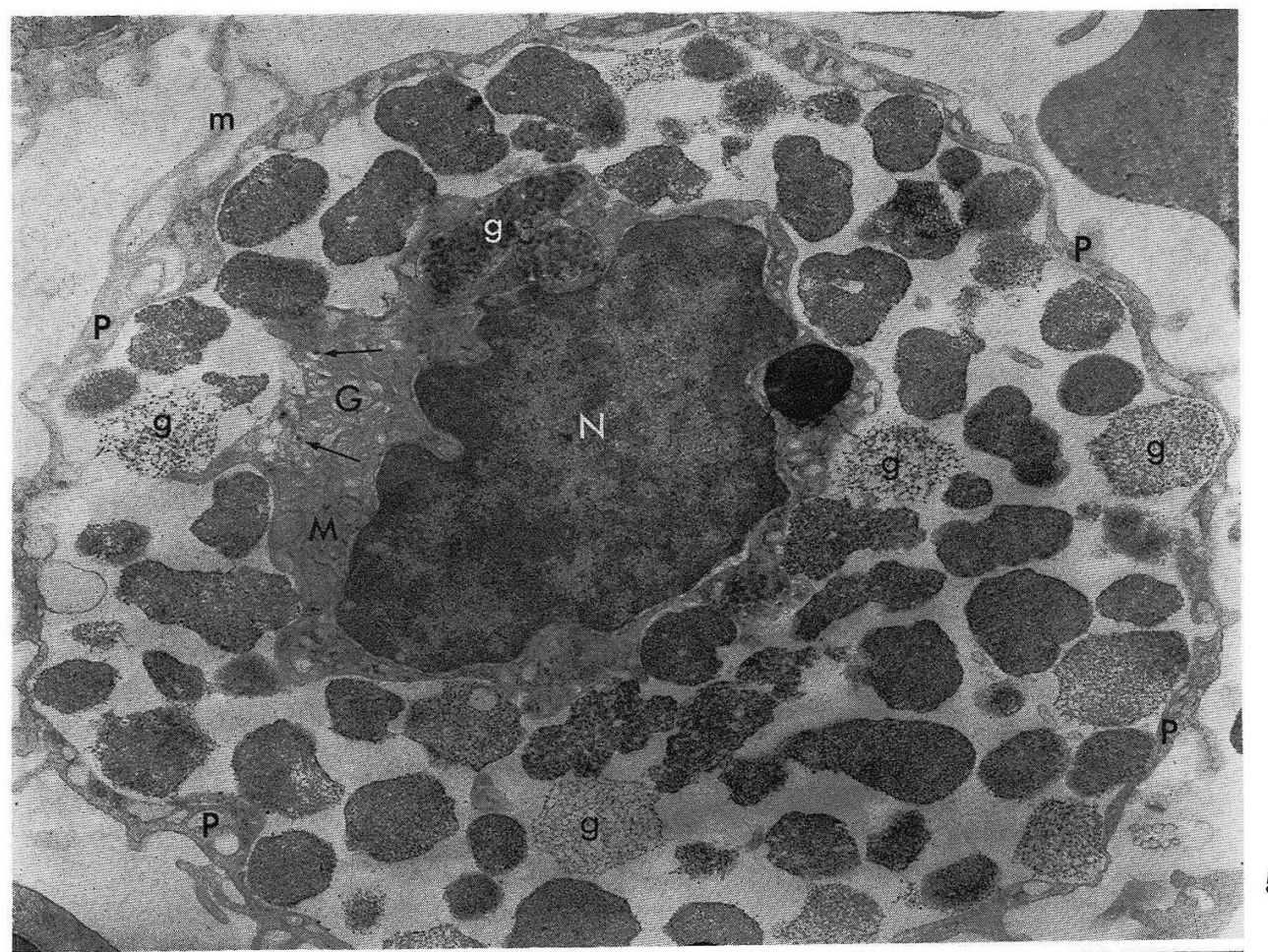

Fig. 5. "Cavity type" cell caused by $1.0 \mu \mathrm{g} / \mathrm{ml}$ compound 48/80. The cytoplasm containing a Golgi area $(G)$ with small granules (arrows), mitochondria $(M)$ and mulberry-like granules remains around the nucleus $(N)$. Some of the granules floating in the cavity show loosened reticular texture $(g)$. The peripheral cytoplasmic sheet $(P)$ retains microvilli $(m) . \quad \times 9,000$

Fig. 6. A cytoplasmic mass remaining at the peripheral region of a cell of "cavity type" lesion. G Golgi complex containing small granules (arrows), $C$ centriol, $M$ mitochondria, $P$ peripheral cytoplasmic sheet. $\times 10,000$

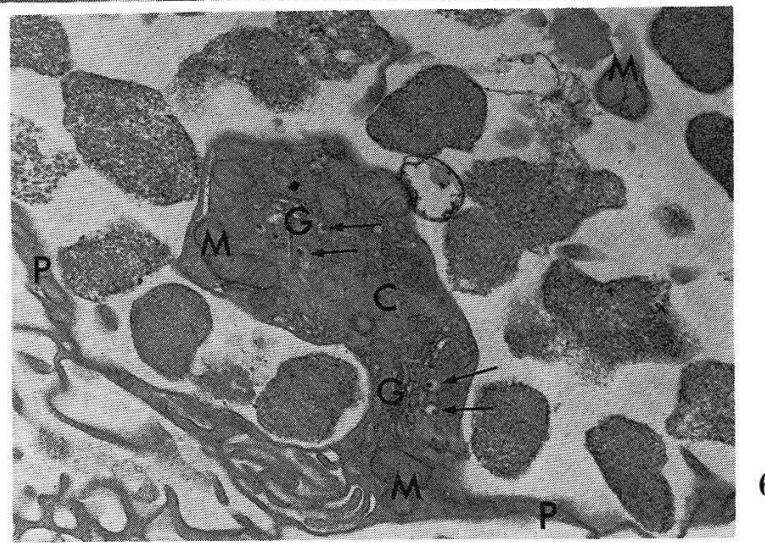


remained only like a loose ball of waste threads, one occasionally found dense granules showing neither apparent changes in the granule texture nor remarkable vaculoles around them. Some cells showed figures of degranulation which will be depicted in the following description of the higher dose administration. A few cells, on the other hand, seemed completely free from the effect of compound 48/80.

The morphological changes described above essentially coincide with the findings of Bloom and HaEgermark (1965) obtained with the corresponding dose of the same substance.

1.0 and $5.0 \mu \mathrm{g} / \mathrm{ml}$. Obvious cytological changes occurred in every mast cell with these doses. As compared with the findings with the preceding dose, far more granules were discharged from the cells and the vacuolation of the cytoplasm was more advanced. Though essentially identical, the changes caused by $5.0 \mu \mathrm{g} / \mathrm{ml}$ were more conspicuous than those caused by $1.0 \mu \mathrm{g} / \mathrm{ml}$.

The cells tended to show either one of two different patterns in vacuolation. The one was represented by cells whose vacuoles were individually enlarged around each granule giving a honeycomb appearance to the cytoplasm. Many of the vacuoles in the periphery opened into the pericellular space and this caused frequent escape of granules from the cell (Fig. 4). This type of vacuole may tentatively be called the "honeycomb type."

The other type which may be called the "cavity type" was characterized by the formation of a single huge vacuole or cavity which contained numerous granules in



Fig. 7. Effects of $100 \mu \mathrm{g} / \mathrm{ml}$ compound $48 / 80$. Although the vacuoles are open in many places to the pericellular space (arrows), no granules are released over the outline of the cell. $M$ mitochondria. $\times 10,000$ 
common and occupied a large cytoplasmic area intermediate between the nucleus and cell surface. The suppressed cytoplasm containing the Golgi complex, mitochondria and immature granules remained in the perinuclear and occasionally also in the peripheral regions (Fig. 5, 6). The peripheral cytoplasmic sheet retained most of the microvilli. An interruption of this sheet was recognized only rarely in the dose of 1.0 $\mu \mathrm{g} / \mathrm{ml}$, whereas in the cases of $5.0 \mu \mathrm{g} / \mathrm{ml}$ the cavity often was widely opened in many places and only a few granules remained within it. The cavity type cells seemed to exceed the "honeycomb type" in number.

$100 \mu \mathrm{g} / \mathrm{ml}$. The effects of this unusually large dose conspicuously differed from those of the small doses described above. Although the vacuoles which filled the cytoplasm of every mast cell were confluent with each other and the septa of the vacuoles were interrupted and attenuated, the large single vacuole as seen in the "cavity type" cells with the preceding dose did not occur. The majority of the granules were neither enlarged (diameter: 0.8-1.2 $\mu$ ) nor changed in fine structure (Fig. 7). Remarkably enough, most cells were devoid of any figure of degranulation, although some granules directly faced the pcricellular space. Discharged granules, if present, remained in the vicinity of the cell.

\section{Toluidine blue $50 \mu \mathrm{g} / \mathrm{ml}$}

The changes caused byt his dose of toluidine blue were essentially not different from those in the case of $1 \mu \mathrm{g} / \mathrm{ml}$ of compound $48 / 80$. Both "honeycomb" and "cavity"
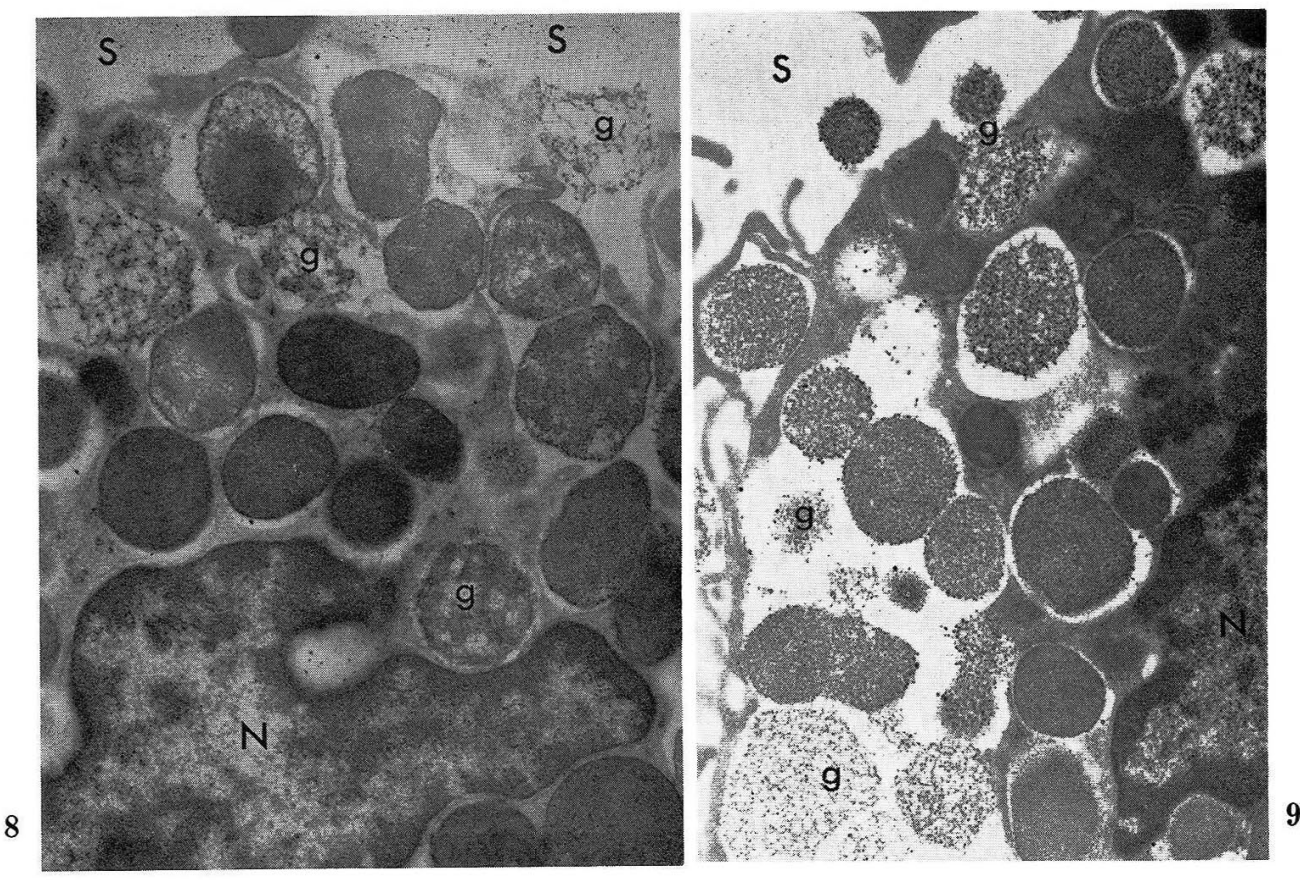

Figs. 8 and 9. Effects of $50 \mu \mathrm{g} / \mathrm{ml}$ toluidine blue (Fig. 8) and of $500 \mu \mathrm{g} / \mathrm{ml}$ sinomenine (Fig. 9). Most granules are loosened in texture $(g)$ and some are discharged into the pericellular space $(S)$. $\times 10,000$ 
types of cells were recognized, degranulation occurring mainly in the former. The swelling $(1.0-1.6 \mu)$ and a coarse and low-density appearance of the granules were conspicuous also (Fig. 8).

\section{Sinomenine $500 \mu \mathrm{g} / \mathrm{ml}$}

The changes in the mast cells caused by this substance resembled those caused by 0.5 and $1.0 \mu \mathrm{g} / \mathrm{ml}$ doses of compound $48 / 80$. The "honeycomb" and "cavity" type cells were found and degranulation occurred mainly in the former cells (Fig. 9).

\section{Anti-rat rabbit serum $10 \%$}

Almost every cell showed severe vacuolation and degranulation in this condition. The swelling (1.0-1.8 $\mu$ ) and structural damage in the granules were morc advanced than in the cases of compound $48 / 80$ administration. A coarse reticular texture and confluence of the granules were more conspicuous. In contrast with the effect of compound $48 / 80$, only the "honeycomb type" vacuolation was recognized. The peripheral vacuoles were ruptured and numerous granules were scattered out of the cell (Fig. 10). Many cells were virtually devoid of granules.

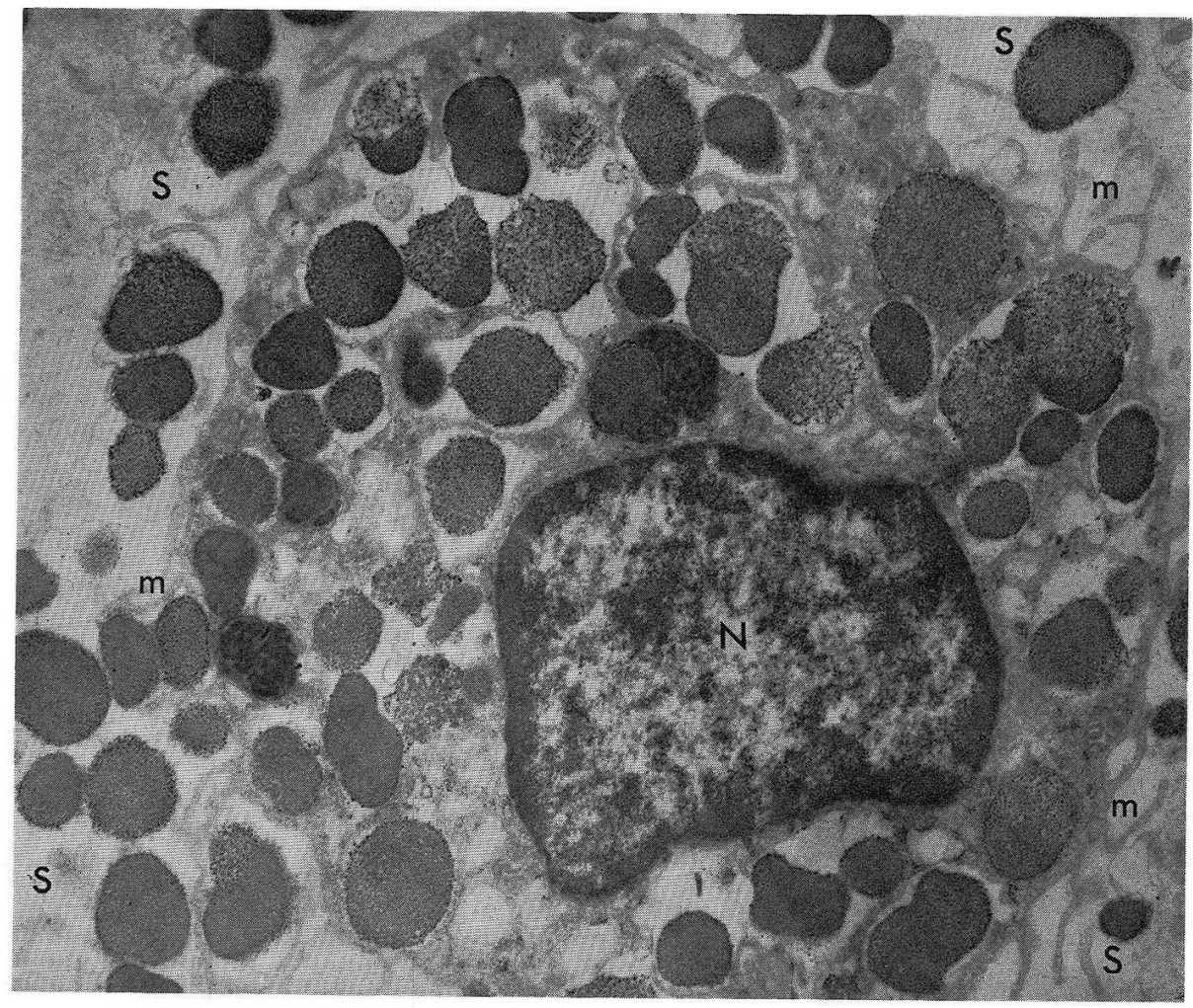

Fig. 10. Treatment with $10 \%$ anti-rat rabbit seum. Notice the strong vacuolation and degranulation. $S$ pericellular space, $m$ microvilli. $\quad \times 10,000$ 


\section{Effect of 2,4-dinitrophenol}

After treatment with $10^{-4} \mathrm{M}$ concentration of DNP, morphological change was recognized neither in the mast cell granules nor in the cytoplasm as compared with the normal cells.

Essentially no changes were caused by $1.0 \mu \mathrm{g} / \mathrm{ml}$ of compound $48 / 80$ when the cells were previously treated with $10^{-4} \mathrm{M}$ concentration of DNP (Fig. 11). Only rarely cells with granules of lowered density and enclosed in vacuoles were encountered.

\section{Discussion}

\section{Morphological manifestations of histamine release}

Three morphological changes in mast cells have been described as accompanying the release of histamine: the degranulation, vacuolation and the altered structure of the granules.

Degranulation or the discharge of mast cell granules has long been a priori believed to be an essential process in the release of histamine (FAWCETT, 1954; RILEY and West, 1955; Kelsall and CrafF, 1959). This view was supported by Uvnës (1964) who made a systematic study on the mechanism of histamine release from mast cells by morphological and bioassay techniques. Sмітн (1958 a, b), on the contrary, described that toluidine blue could release histamine without degranulation of the mast cells.

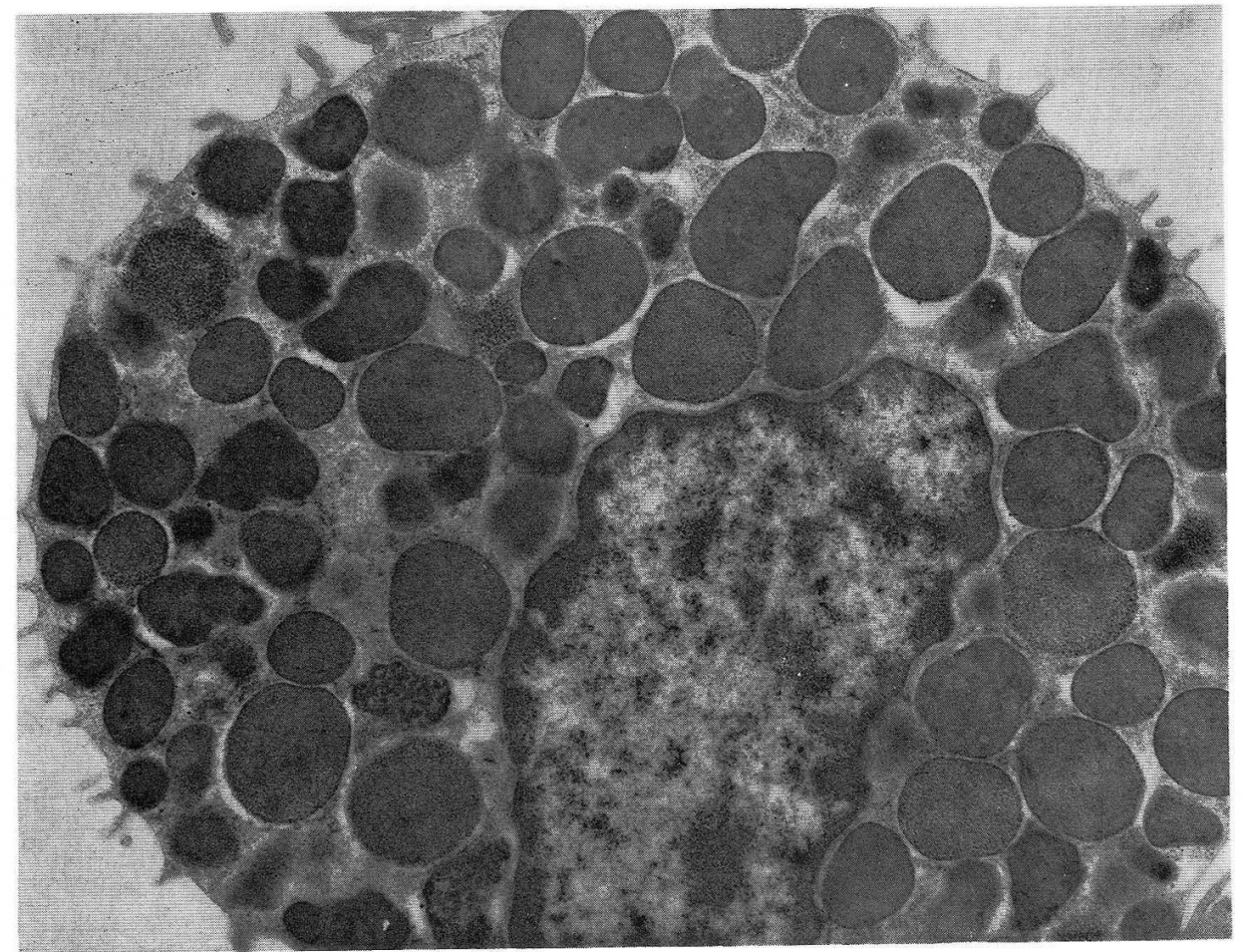

Fig. 11. Effects of $1.0 \mu \mathrm{g} / \mathrm{ml}$ compound $48 / 80$ after pretreatment of the cells with DNP. No cytological change is recognizable. $\times 10,000$ 
In the rat peritoneal mast cells treated with $100 \mu \mathrm{g} / \mathrm{ml}$ compound 48/80, Комото (unpublished observation) previously recognized no degranulation under the phasecontrast microscope, although he estimated more than $90 \%$ of the histamine lost from the cells. The present electron microscopic study has given the answer to this apparently controversial result: the granules floated in the vacuoles which were here and there continuous to the pericellular space, in other words they have become free not out of the cell but within the cell. The present bioassay result, in accordance with the observation by Комото, indicates that $90 \%$ of the histamine has been lost from these cells.

It has thus become clear that degranulation is neither the essential condition for the release of histamine nor its reliable criterion under the light and electron microscopes. Vacuolation or enlargement of the perigranular spaces into vacuoles, on the other hand, seems to be a more concrete manifestation of the release of histamine. As a matter of fact, the present observations revealed perigranular vacuolation in every experimental case in which histamine release was detected, and these two events appeared to be roughly parallel in extent. With a small dose of compound $48 / 80$, such as $0.1 \mu \mathrm{g} / \mathrm{ml}$, about $38 \%$ of the histamine was released. In this case, there was neither extracellular detrusion of granules nor visible discontinuation of the cellular membrane in most mast cells, but vacuolation was observed around granules in a considerable number of cells. These observations strongly suggest that vacuolation is a process inevitable for the induction of degranulation, and that histamine is released already during the stage of vacuolation. Whether the stage of degranulation follows or, as we saw in the case of $100 \mu \mathrm{g} / \mathrm{ml}$ as well as $0.1 \mu \mathrm{g} / \mathrm{ml}$ of compound $48 / 80$, not, seems indifferent to the phenomenon of histamine release. It is not known whether the continuity of the vacuoles to the pericellular space is necessary for the release of histamine from the cell, as histamine released in the vacuoles may possibly pass through the cytoplasmic sheets.

The third cytological change which has been thought related to the release of histamine concerns the fine structure of the granules. Lowered electron density and loosened architecture of the granules have repeatedly been described as the morphological criteria of histamine release (Horsfield, 1965; Bloom and HAEgermark, 1965). The present observation, though it showed a tendency of these "altered granules" (designation by BLOOM and HAEGERMARK, 1965) to occur more frequently under the experimental conditions causing the release of higher amounts of histamine, also revealed some exceptions. The granules in the case of $100 \mu \mathrm{g} / \mathrm{ml}$ of compound $48 / 80$, for instance, were only inconspicuously altered. On the other hand, the untreated mast cells sometimes contained a considerable population of granules of the "altered" type. It is unknown as yet whether this corresponds, as postulated by BLoom and HAEGERmark (1965), to a possible "spontaneous release" of histamine in untreated mast cells or to some physical or chemical event in the granules not directly related to histamine release. It is to be remembered in this connection that FuJITA (1965) described in the normal subcutaneous mast cells of the rat a large clump of granules of the altered type which he regarded as aged granules. He showed, on the other hand, the occurrence of compact and electron dense granules in the mast cells of the juvenile rat in which vacuolation and degranulation were conspicuous. These and the present findings imply that the relation of the structure of the granules to the release of 
histamine is still problematical and that the occurrence of the altered type of granules should be referred to in the consideration of histamine release with certain reservations.

\section{Differences in the effects of histamine-releasing factors}

Toluidine blue has long been known to stain the mast cell granules metachromatically. The ability of this dye to release histamine was discovered rather recently (Sмith, 1958; Riley, 1959). Sinomenine is an alkaloid obtained from a plant Sinomenium acutum REHDER et WILSON and its histamine-releasing effect was established by MAYEDA (1953). Комото and YAмASAKI (1967) who observed the changes of the rat peritoneal mast cells under the phase-contrast microscope indicated that the administration of $50 \mu \mathrm{g} / \mathrm{ml}$ of toluidine blue causes vacuolation and degranulation in almost every cell and release of $60-80 \%$ of the histamine. According to a simjlar study by YAMASAKI and SAEKI (1965) $400 \mu \mathrm{g} / \mathrm{ml}$ of sinomenine causes the same changes in about $90 \%$ of the mast cells and the release of about $80 \%$ of the total histamine contained in the cells. These studies further emphasized that the cytological changes brought about by these histamine liberators coincided with those caused by compound $48 / 80$ in that they proceeded very rapidly and that they were inhibited by the presence of DNP and other metabolic inhibitors. The present electron microscopic findings obtained by the use of $50 \mu \mathrm{g} / \mathrm{ml}$ of toluidine blue and $500 \mu \mathrm{g} / \mathrm{ml}$ of sinomenine also correspond well to the changes caused by compound $48 / 80$ in concentrations $(0.5-1.0 \mu \mathrm{g} / \mathrm{ml})$ causing comparable histamine-release activities (cf. Table 1). It is thus likely that all these substances act on the mast cell with the same mechanism.

As for the changes in mast cells in antigen-antibody reaction there is available the phase-contrast microscopic observation of SAEKI (1964) on rat peritoneal mast cells affected by $10 \%$ anti-rat rabbit serum. He found that the changes in the cells including the formation of large vacuoles and degranulation proceeded much more slowly than in the cases of compound $48 / 80$ and other basic histamine liberators mentioned above. Moreover, the discharged granules appeared conspicuously large as compared with the latter cases. The present electron microscopic observations also confirmed that the pattern of the cytoplasmic and granule changes caused by anti-rat rabbit serum considerably differs from that caused by compound $48 / 80$. These differences seem to imply the possible difference in the mechanisms of the reactions of mast cells to both histamine-releasing agents.

It has been postulated that antibodies are bound to the plasma membrane of mast cells and the attachment of antigens to them causes an imbalance in that site which seems to bring about a series of cytological changes including degranulation (HUMPHREY and Mota, 1959; Mota, 1959; Keller and Schwarz, 1961). Movat, Lovett and TAICHMAN (1966) who treated rat cutaneous mast cells with anti-ferritin antibody and then challenged with antigen, recognized the aggregation of the latter on the plasma membrane and on the granule surface. In the present study and SAEkI's study mentioned above, on the other hand, antibody was administered so that it might be bound to the antigen in the cells. The first work along this line seems to be the experiment by WEGELIUS and his co-workers (1955) in which severe degranulation of hamster mast cells was caused by the administration of rabbit anti-hamster serum. In this "reverse type of anaphylaxis" the antigen present in the plasma membrane may likely be first combined with the antibody and this may, by unknown mechanisms not the same as 
chemicalliberators, trigger the cytological changes and then histamine release.

DNP uncouples the oxidative phosphorization in mitochondria. SAEKI (1964) found that the administration of $10^{-4} \mathrm{M}$ concentration of this substance to the rat mast cells incubated in a medium containing no glucose almost completely inhibited the degranulating effect of later treatment with $0.5 \mu \mathrm{g} / \mathrm{ml}$ of compound $48 / 80$. This inhibitory action of DNP did not work any more when glucose was added to the medium so that ATP might be produced by the glycolytic system (SAEKI, 1964). We also found that only $6.5 \%$ of the histamine was released by $1.0 \mu \mathrm{g} / \mathrm{ml}$ compound $48 / 80$ when the cells were treated with the same concentration of DNP in the glucose-free medium. The same experiment revealed under the electron microscope that the cells were prevented by DNP from reacting to the subsequent invasion of the histamine liberator. The vacuoles occasionally encountered may correspond to the minute histamine release mentioned above. The view that the non-reactivity of the cells to the histamine liberator should be ascribed not to the death of the cells but rather to the lack of ATP seemed to be supported by the present electron microscopic findings indicating no degenerative changes in the cells.

\section{Summary}

The effects of some histamine-liberating agents on rat peritoneal mast cells were examined under the electron microscope and the release of histamine was measured by means of bioassay.

Compound $48 / 80$, when given in a small dose $(0.1 \mu \mathrm{g} / \mathrm{ml})$, caused swelling of the granules and widening of the perigranular space only in a small part of the cells. With moderate doses $(1.0-5.0 \mu \mathrm{g} / \mathrm{ml})$, perigranular vacuoles developed either individually causing a honeycomb-like cytoplasm or, by confluence, into a single large vacuole leaving a thin cytoplasmic sheet at the periphery of the cell. Degranulation occurred mainly in the cells with the former type of vacuolation. When a very large dose $(100 \mu \mathrm{g} / \mathrm{ml})$ of compound $48 / 80$ was given, vacuolation was marked but the granules were neither discharged nor swollen. Toluidine blue $(50 \mu \mathrm{g} / \mathrm{ml})$ and sinomenine $(500 \mu \mathrm{g} / \mathrm{ml})$ caused cytological changes in the mast cells similar to those under moderate dose treatment with compound $48 / 80$. The effect of anti-rat rabbit serum was characterized by greater swelling of the granules and more conspicuous peripheral vacuolation than in the cases of the histamine liberators. Pretreatment with $10^{-4} \mathrm{M}$ of 2,4-dinitrophenol almost completely inhibited any cytological change inducible by compound $48 / 80$.

By comparing the electron micrographs with the grades of histamine release in the corresponding cases measured by bioassay (Table 1), it was proposed that the most reliable morphological criterion of the release of histamine is neither degranulation nor granule swelling, but the occurrence of vacuoles around the granules.

Acknowledgment. The authors acknowledge the technical assistance of Mr. Hirotaka KAwAKAmi, Department of Anatomy, and Mr. Nobuo Hayashi and Mr. Noboru Saibara of the Central Laboratory, Okayama University Medical School. 


\section{電子顕微鏡によるラット腹水肥満細胞のヒスタミン遊離過程の研究}

\section{(内容自抄)}

ラットの腹水から得られた肥満細胞に, 種々のヒスタミン遊離物質を与え, 細胞の形 態变化を電子顕微鏡で分析し，ヒスタミンの放出量をバイオアッセイにより測定した.

Compound 48/80 の少量投与 $(0.1 \mu \mathrm{g} / \mathrm{ml})$ では, 一部の細胞だけに顆粒の膨化と顆粒 周囲の空吵の開大が見られた. 中等度の用量 (1.0-5.0 $\mu \mathrm{g} / \mathrm{ml})$ では 顆粒周囲の空胞が発 達して蜂の巣状を呈する細胞と，空胞の融合により単一の巨大な空胞を形成して 周囲に 細胞質の薄層を残すものが見られた. 脱顆粒はとくに蜂の巣状の細胞に著しい. 著しく 大量 $(100 \mu \mathrm{g} / \mathrm{ml})$ を投与するときは，空胞形成はおこるが 顆粒の放出と膨化は見られ ない.トルイジン青 $(50 \mu \mathrm{g} / \mathrm{ml})$ とシノメニン $(500 \mu \mathrm{g} / \mathrm{ml})$ による肥満細胞の变化は, 中等量の compound 48/80 を投与した場合と同様であった. 抗ラットウサギ血清の効 果は，強い顆粒膨化と細胞周辺部の激しい空胞化を示し，上記ヒスタミン遊離剤による 変化と趣を異にしていた。 あらかじめ 2,4-dinitrophenol $\left(10^{-4} \mathrm{M}\right)$ で処理した肥満細胞 に compound 48/80を与えると，何の变化も㧍こらない.

これらの電子顕微鏡像を実験各例について測定されたヒスタミン放出量と比較検討し た結果, ヒスタミン遊離の最も確かな形態学的示標は脱顆粒や顆粒の膨化ではなく, 顆 粒周囲の空胞出現であることが結論された.

\section{References}

Bloom, G. and Ö. Haegermark: A study on morphological changes and histamine release induced by compound 48/80 in rat peritoneal mast cells. Exp. Cell Res. 40: 637-654 (1965).

Bloom, G., B. Larsson and D. E. Smith: The reaction of peritoneal mast cells in the rat to various activators. Acta pathol. microbiol. scand. 40: 309-315 (1957).

Camble, P.: Siderosis and mast cell vacuolation in albino rat after toluidine blue-O administration. Fed. Proc. 11: 409-410 (1952).

Combs, J. W.: Maturation of rat mast cells. An electron microscope study. J. Cell Biol. 31: 563575 (1966).

Diamant, B. and B. Uvnäs: Evidence for energy-requiring processes in histamine release and mast cell degranulation in rat tissues induced by compound 48/80. Acta physiol. scand. 53: 315-329 (1961).

Fawcett, D. W.: Cytological and pharmacological observations on the release of histamine by mast cells. J. exp. Med. 100: 217-224 (1954).

Fujita, T.: Über die Granula der Gewebsmastzellen der Ratte. Z. Zellforsch. 66: 66-82 (1965).

Ginsburg, H. and D. Lagunoff: The in vitro differentiation of mast cells. Cultures of cells from immunized mouse lymphnodes and thoracic duct lymph on fibroblast monolayers. J. Cell. Biol. 35: 685-697 (1967).

Hagen, P. B., R. J. Barrnett and F. L. Lee: Biochemical and electron microscopic study of particles isolated from mastcytoma cells. J. Pharmacol. exp. Ther. 126: 91-97 (1959).

Horsfield, G. I.: The effect of compound $48 / 80$ on the rat mast cell. J. Pathol. Bacteriol. 90: 599605 (1965).

Humphrey, J. H. and I. Mota: The mechanism of anaphylaxis: specificity of antigen-induced mast cell damage in anaphylaxis in the guinea pig. Immunol. 2: 31-34 (1959). 
Juhlin, L. and W. B. Shelley: Detection of histamine by a new fluorescent 0 -phthalaldehyde stain. J. Histochem. Cytochem. 14: 525-528 (1966).

Karnovsky, M.: Simple methods for "staining with lead" at high $\mathrm{pH}$ in electron microscopy. J. biophys. biochem. Cytol. 11: 729-732 (1961).

Keller, R. and M. Schwarz: Zem immunologischen Verhalten isolierter Mastzellen. Int. Arch. Allergy 19: 202-209 (1961).

- - Versuch zur Charakterisierung der anaphylaktischen Reaktion isolierter Gewebsmastzellen der Albino Ratte mittels spezifischer Antiseren. Pathol. Microbiol. 26: 100-107 (1963).

Kelsall, M. A. and E. D. Crabb: Lymphocytes and mast cells. Baltimore, Williams \& Wilkins Co., 1959.

Komoto, S. and $\mathbf{H}$. Yamasaki: The mechanism of histamine release by toluidine blue from isolated rat mast cells (in Japanese). Fol. pharmacol. jap. 63: 146§ (1967).

Mayeda, H.: The release of histamine by sinomenine. Jap. J. Pharmacol. 3: 62-72 (1953).

Millonig, G. A.: A modified procedure for lead staining of thin sections. J. biophys. biochem. Cytol. 11: 736-739 (1961).

Mota, I.: Effect of antigen and octylamine on mast cells and histamine content of sensitized guineapig tissues. J. Physiol. 147: 425-436 (1959).

Movat, H. Z., C. A. Lovett and N. S. Taichman: Demonstration of antigen on the surface of sensitized rat mast cells. Nature 212: 851-853 (1966).

Ohara, Y.: An electron microscopic study on isolated rat mast cells under the effect of histamine liberators (in Japanese). Fol. pharmacol. Jap. 65: 273-288 (1969).

Paton, W. D. M.: Compound 48/80, a potent histamine liberator. Brit. J. Pharmacol. 6: 499-508 (1951).

Riley, J. F.: The Mast Cells. Edinburgh, Livingstone Ltd. 1959 (p. 124).

Riley, J. F. and G. B. West: The presence of histamine in tissue mast cells. J. Physiol. 120: 528537 (1953). 48/80). J. Pathol. Bacteriol. 69: 269-282 (1955)

Saeki, K.: Effects of compound 48/80, chymotrypsin and anti-serum on isolated mast cells under aerobic and anaerobic conditions. Jap. J. Pharmacol. 14: 375-390 (1964).

Singleton, E. M. and S. L. Clark, Jr.: The response of mast cells to compound 48/80 studied with the electron microscope. Lab. Invest. 14: 1744-1763 (1965).

Smith, D. E.: Nature of the secretory activity of the mast cell. Amer. J. Physiol. 193: 573-575 (1958a).

-: Dynamics of release of histamine from tissue mast cell. Science 128: 207 (1958b).

Smith, D. E. and Y. S. Lewis: Electron microscopy of the tissue mast cells. J. biophys. biochem. Cytol. 3: 9-14 (1957).

Takaya, K.: The relationship between mast cells and histamine in phylogeny with special reference to reptiles and birds. Arch. histol. jap. 30: 401-420 (1969).

Uvnäs, B.: Release processes in mast cells and their activation by injury. Ann. N. Y. Acad. Sci. 116: 880-890 (1964).

Yamasaki, H.: The release of histamine and its mechanism. Proc. 17. Jap. Med. Congr. 1: 555-578 (1967).

Yamasaki, H., A. Kuroda, Y. Kamimura, K. Sanuki, K. Tasaka, R. Nishiyama, M. Kume and S. Kawamoto: Studies on the histamine release by chemical substances. Proc. 14. Jap. Med. Congr. 2: 45-48 (1955).

Yamasaki, H. and $\mathbf{K}$. Saeki: Evidence for energy-requiring processes in mast cell degranulation and histamine release in rat induced by sinomenine. Proc. Jap. Acad. 41: 958-962 (1965).

Wegelius, O., G. Hjelmman and C. Wasastjerna: Morphological changes caused by anti-hamster serum in the mast cells of the hamster. Acta pathol. microbiol. scand. 36: 309-315 (1955). 